\title{
USULAN PERBAIKAN POSTUR KERJA OPERATOR PROSES PRODUKSI BATIK CAP DI BATIK PUTRI MULYO DENGAN METODE VISUAL MANAGEMENT
}

\author{
Anita Rosifah $^{1)}$, Susy Susmartini ${ }^{2)}$, dan Irwan Iftadi ${ }^{3)}$ \\ ${ }^{1)}$ Program Studi Teknik Industri, Fakultas Teknik, Universitas Sebelas Maret Jl. Ir. Sutami 36A, Surakarta 57126, \\ Indonesia \\ ${ }^{2)}$ Program Studi Teknik Industri, Fakultas Teknik, Universitas Sebelas Maret Jl. Ir. Sutami 36A, Surakarta 57126, \\ Indonesia \\ ${ }^{3}$ Program Studi Teknik Industri, Fakultas Teknik, Universitas Sebelas Maret Jl. Ir. Sutami 36A, Surakarta 57126, \\ Indonesia
}

\begin{abstract}
Observations made at work stations of batik cap production, there are still some working conditions that are not appropriate on their worker, one of which is unnatural posture. Unusual work postures that can trigger the occurrence of pain complaints such as musculoskeletal disorders (musculoskeletal disorders). Often unwittingly, batik workers work with positions or postures that have health risks such as musculoskeletal disorders (MSDs). Based on the observation seen that at the work station batik production there are some problems related work methods. Therefore, to improve which work station needs to be repaired, it is necessary to do risk assessment of batik production station work posture using Visual Management approach.

The Visual Management approach in this study uses the ergonomic analysis method for the whole body of REBA (Rapid Entire Body Assessment) and OWAS (Ovako Working Posture Analysis System), upper limb RULA (Rapid Upper limb Assessment) and OCRA checklist and by adding some aspects Associated with overload and repetitiveness in the OCRA checklist and OWAS.

Based on the assessment of work posture by visual management method, the result of OES value shows 3 processes with OES value $\leq 0.4$ with accepted operational status and 2 process with OES value is in the range 0.4 $<O E S \leq 0.5$, with operational status becomes' necessary further investigation, Changes may be required
\end{abstract}

Keywords: work Posture, visual management, batik workers

\section{PENDAHULUAN}

Pengamatan yang dilakukan di stasiun kerja pembuatan batik cap masih terdapat beberapa kondisi kerja yang tidak sesuai pada pekerjanya, interaksinya dengan produk, peralatan, fasilitas, prosedur, lingkungan dan pekerja yang ada didalamnya serta kehidupan sehari-hari dimana penekanannya adalah faktor pekerja. Hal tersebut diperkuat dengan tingkat kelelahan pekerja yang tinggi dan menyebabkan produktivitas kerja yang rendah.

Postur kerja merupakan pengaturan sikap tubuh saat bekerja. Sikap kerja yang sering dilakukan oleh manusia dalam melakukan pekerjaan antara lain berdiri, membungkuk, jongkok, berjalan, dan lain-lain (Bridger, 1995). Posisi kaki dalam kondisi diam, dimana sendi, dan lutut tidak bergerak/bergeser dalam jangka waktu yang lama serta memanfaatkan tenaga yang sedikit, merupakan sikap kerja yang tidak alamiah (Grandjean, 1998). Postur kerja yang tidak alamiah tersebut dapat memicu terjadinya keluhan rasa nyeri seperti gangguan muskuloskeletal (musculoskeletal disorders) (Budiman, 2015). Sering kali tanpa disadari para pekerja batik bekerja dengan posisi atau postur yang memiliki risiko pada kesehatan seperti musculoskeletal disorders (MSDs).

Keluhan MSDs disebabkan karena sistem kerja pada sebagian besar industri batik di Solo masih banyak yang dikerjakan secara manual dan memerlukan tuntutan serta tekanan secara fisik yang berat sehingga hal tersebut dapat menyebab keluhan akibat gangguan muskuloskeletal, kelelahan, beban kerja, dan risiko cedera yang dialami oleh pekerja. Dengan munculnya berbagai komplain baik secara fisik maupun psikis, maka sudah barang tentu akan menurunkan performasi kerja yang pada akhirnya akan menurunkan produktivitas kerja (Tarwaka, 2011). Berkaitan dengan permasalah tersebut penciptaan sistem kerja yang memperhatikan kaidah ergonomi akan sangat membantu meningkatkan efektivitas dan reliabilitas istem kerja, meningkatkan produktivitas, mengurangi biaya pemerliharaan kesehatan pekerja, dan meningkatkan kualitas proses kerja, produk serta peningkatan kesejahteraan hidup pekerja.

Berdasarkan pengamatan dan wawancara terhadap pemilik Batik Putri Mulyo, terdapat keluhan sistem produksi yang kurang memenuhi target. Selain itu terdapat bagian di mana postur kerja operator dipandang kurang ergonomis karena operator melakukan sikap kerja yang salah (awkward posture). Hal ini diperkuat dengan operator sering melakukan istirahat saat proses produksi berlangsung. Dari pengamatan tersebut terlihat bahwa pada stasiun kerja produksi batik terdapat permasalahan terkait metode kerja, untuk 
memperbaiki stasiun kerja mana yang perlu diperbaiki maka perlu dilakukan penyebaran kuesioner. Hasil kuesioner yang diperoleh, menunjukan stasiun kerja yang memiliki tingkat keluhan paling tinggi yang kemudian dilakukan penilaian risiko postur kerja stasiun produksi batik menggunakan pendekatan Visual Management.

Pendekatan Visual Management merupakan metode yang dihasilkan dengan cara meringkas metode analisis postur kerja yang sudah sering digunakan, yaitu metode analisis ergonomi untuk seluruh tubuh REBA (Rapid Entire Body Assessment) dan OWAS (Ovako Working Posture Analysis System), metode analisis upper limb RULA (Rapid Upper limb Assessment) dan OCRA checklist dan dengan menambahkan beberapa aspek yang berhubungan dengan beban berlebih (overload) dan pengulangan (repetitiveness) dalam OCRA checklist dan OWAS (Savino, Mazza, and Battini, 2016).

Hasil dari analisis postur kerja dengan pendekatan Visual Management berupa skor ergonomi atau OES (Overall Ergonomic Scores) yang memiliki empat interval yang memberikan indikasi kekritisan postur kerja disertai dengan derajat kepentingan perbaikan sistem kerja. Perbaikan akan dilakukan untuk mengurangi bahaya terhadap muskuloskeletal dengan menerapkan perancangan sistem kerja.

Berdasarkan latar belakang di atas, permasalahan yang akan dikaji dalam penelitian ini yaitu "bagaimana melakukan perbaikan sistem kerja dengan merancang alat bantu berdasarkan hasil analisis Visual Management?"

\section{Tujuan Penelitian}

Berdasarkan perumusan masalah yang telah dikemukakan, maka penelitian ini bertujuan

1. Mendapatkan hasil analisis postur kerja yang mempunyai derajat kepentingan perbaikan tertinggi menurut metode visual management.

2. Merancang suatu alat bantu yang memperbaiki postur kerja pada stasiun kerja dengan derajat kepentingan perbaikan tertinggi.

\section{TINJAUAN PUSTAKA}

\subsection{Ergonomi}

Ergonomi disebut juga sebagai "Human Factors".Pembahasan tentang ergonomic membutuhkan studi tentang sistem manusia, di mana manusia, fasilitas kerja, dan lingkungan saling berinteraksi dengan tujuan utama yaitu menyesuaikan suasana kerja dengan manusianya. Penerapan ergonomi umumnya meliputi aktivitas rancang bangun (design) maupun rancang ulang (re-design). Hal ini dapat mencakup perangkat keras seperti perkakas kerja (tools), bangku kerja (benches), platform, kursi, pegangan alat kerja (workholders), sistem pengendali (controls), alat peraga (displays), jalan/lorong (acces ways), pintu (doors), jendela (windows), dan lain-lain.

Ergonomi industri adalah penerapan berbagai ilmu pengetahuan yang menghubungkan performansi manusia dengan perbaikan sistem kerja yang terdiri dari pekerja, pekerjaan, peralatan dan perlengkapan, ruang kerja dan tempat kerja, dan lingkungannya (Alexander, 1986).

\subsection{Keluhan Muskuloskeletal}

Grandjean (1993) mengemukakan bahwa keluhan muskuloskeletal adalah keluhan yang terjadi pada bagian - bagian otot maupun kerangka yang ditandai dengan adanya rasa sakit ringan sampai pada rasa sakit yang akut. Otot yang menerima beban statis terus - menerus secara berulang akan mengakibatkan kerusakan pada ligament dan tendon. Kerusakan inilah yang menyebabkan keluhan yang disebut dengan musculoskeletal disorders (MSDs) (Grandjean, 1993).

\subsection{Analisis Postur Kerja Terhadap Gangguan Muskuloskeletal}

Terdapat empat faktor yang dapat meningkatkan timbulnya gangguan muskuloskeletal yaitu: postur yang tidak alamiah, tenaga yang berlebihan, pengulangan berkali-kali, dan lamanya waktu kerja. Munculnya keluhan muskuloskeletal dari yang paling ringan hingga yang berat akan menggangu konsentrasi dalam bekerja, menimbulkan kelelahan dan pada akhirnya akan menurunkan produktivitas kerja seseorang (Hagberg et al., 1997).

\section{Postur Kerja atau Sikap Kerja}

Sikap kerja yang sering dilakukan oleh manusia dalam melakukan pekerjaan antara lain berdiri, duduk, membungkuk, jongkok, berjalan, dan lain-lain. Sikap kerja tersebut dilakukan tergantung dari kondisi dari sistem kerja yang ada. Jika kondisi sistem kerjanya tidak sehat akan menyebabkan kecelakaan kerja, karena pekerja melakukan pekerjaan yang tidak aman. Sikap kerja yang salah, canggung, dan di luar kebiasaan akan menambah resiko cidera pada bagian sistem muskuloskeletal (Bridger, 1995).

Gangguan muskuloskeletal bisa terjadi walaupun tingkat gaya yang dikeluarkan ringan dan postur kerja memuaskan (OHSCO, 2007). Berikut ini adalah jenis MSDs yang dapat diakibatkan oleh postur yang janggal atau tidak alami, yaitu: 
1. Low Back Pain, yaitu rasa sakit akut dan kronis dari tulang belakang pada daerah lumbosacral, pantat, dan kaki bagian atas yang biasanya terjadi karena penipisan intervertebral disc atau berkurangnya cairan pada disk. Biasanya terjadi pada pekerja yang suka mengangkat (Bridger, 2003).

2. Carpal Tunnel Syndrome, yaitu tendon pada carpal tunnel membengkak karena penggunaan yang cepat dan berulang pada jari dan tangan. Menyebabkan nyeri, rasa terbakar, dan kemampuan menggenggam menurun. Biasanya terjadi pada typist (Humantech, 1989,1995).

3. Buristis, yaitu rongga yang berisi cairan pelumas sendi membengkak dan inflamasi sehingga menyebabkan nyeri dan keterbatasan gerak (Bridger, 2003).

4. Epicondylitis, yaitu inflamasi pada otot dan jaringan penghubung yang berada di sekitar siku karena adanya rotasi dan putaran yang terlalu sering. Biasanya sering terjadi pada petenis (Bridger, 2003).

5. Sprain dan strains terjadi saat ligamen atau otot terlalu tertekan karena adanya postur yang memberi beban terhadap tubuh (Bridger, 2003).

6. Ganglion Cyst, yaitu benjolan di bawah kulit yang disebabkan karena akumulasi cairan pada lapisan tendon. Ini biasanya ditemukan pada tangan dan pergelangan tangan (Humantech, 1989, 1995).

7. Tendinitis, yaitu inflamasi pada tendon biasanya terjadi pada tangan dan pergelangan tangan karena pekerjaan menggunakan postur yang tidak biasa secara terus menerus (Bridger, 2003).

8. Tenosynovitis, terjadi karena adanya inflamasi tendon dan pelapisanya dengan pembengkakan pada pergelangan tangan aktivitas yang berlebihan pada tendon yang disebabkan oleh beban dan pergerakan yang berulang (Pulat, 1997).

\subsection{PLIBEL}

PLIBEL adalah checklist penyaringan sederhana yang dimaskudkan untuk menyoroti resiko muskuluskoletal yang berhubungan dengan tempat kerja, aspek waktu, pertimbangan lingkungan dan organisasi bisa dianggap sebagai faktor yang berpengaruh. Metode ini adalah metode penilaian umum, tidak dimaksudkan untuk setiap jenis pekerjaan tertentu. Keuntungan dari metode ini adalah sederhana dan dirancang untuk memeriksa kondisi primer. PLIBEL merupakan metode investigasi awal untuk pengamat tempat kerja untuk mengidentifikasi bahaya ergonomis dan dapat dilengkapi dengan pengukuran lain, misalnya berat dan waktu, atau kutipan pengamatan dari penelitian lain. Kelemahannya adalah metode ini terlalu umum tidak untuk jenis pekerjaan tertentu (Stanton, Hedge, Salas, Hendrick, and Brookhuis, 2005).

PLIBEL adalah alat screening checklist sederhana dimaksudkan untuk menyoroti risiko muskuloskeletal sehubungan dengan penyelidikan tempat kerja. aspek waktu, faktor lingkungan, dan faktor organisasi juga harus dianggap sebagai memodifikasi faktor.

Daftar ceklist ini dirancang sedemikian rupa sehingga item biasanya diperiksa dalam penilaian kerja dari bahaya ergonomi akan terdaftar dan terkait dengan lima wilayah tubuh (Gambar 2.4). Hanya karakteristik pekerjaan yang spesifik, yang didefinisikan dan didokumentasikan sebagai bahaya ergonomi dalam makalah ilmiah atau buku teks, tercantum..

Sebuah penilaian kerja menggunakan PLIBEL dimulai dengan sebuah wawancara pendahuluan dengan karyawan dan observasi awal. bagian perwakilan dari pekerjaan, tugas-tugas yang dilakukan untuk sebagian besar jam kerja, dan tugas-tugas yang pekerja atau pengamat memandang sebagai sangat stres pada sistem muskuloskeletal yang dipilih untuk penilaian. Dengan demikian, beberapa bentuk PLIBEL mungkin harus diisi untuk setiap karyawan.

\subsection{Analisis Postur Kerja Dengan Pendekatan Visual Management}

Pendekatan Visual Management merupakan metode yang dihasilkan dengan cara meringkas metode analisis postur kerja yang sudah sering digunakan, yaitu metode analisis ergonomi untuk seluruh tubuh REBA (Rapid Entire Body Assessment) dan OWAS (Ovako Working Posture Analysis System), metode analisis upper limb RULA (Rapid Upper limb Assessment) dan OCRA checklist dan dengan menambahkan beberapa aspek yang berhubungan dengan beban berlebih (overload) dan pengulangan (repetitiveness) dalam OCRA checklist dan OWAS.

Pendekatan ini dirancang sebagai metode analisis ergonomi seluruh tubuh yang mampu:

a. Mempertimbangkan faktor-faktor tambahan yang terkait dengan tindakan pengulangan (repetitiveness), langkah berjalan (walked steps) dan beban ditangani (loads handled), yang kadang-kadang dikecualikan oleh metode ergonomi lainnya.

b. Mengevaluasi seluruh tubuh, tidak hanya satu bagian tubuh saja

c. Pendekatan Visual Management menawarkan satu set peta penilaian visual ergonomi yang baru dalam rangka mempercepat proses analisis dan mengurangi waktu pelatihan untuk analis.

d. Visual Management mengusulkan pendekatan manajemen visual untuk tindakan identifikasi kebutuhan intervensi, yang menyediakan cara mudah untuk mendeteksi operasi kritis. Prioritas dari intervensi untuk mengurangi risiko ergonomi dicapai dengan menyusun tingkat keparahan operasi dengan diagram Pareto. 


\section{METODOLOGI PENELITIAN}

Metodologi penelitian diawali dengan melakukan observasi lapangan yang dilakukan dengan 2 langkah, yaitu pengamatan langsung dan wawancara dengan stakeholder. Langkah selanjutnya pengumpulan dan pengolahan data. Pengolahan data yang dilakukan yakni dengan menggunakan pendekatan Visual Management. Pendekatan ini merupakan metode yang meringkas REBA (Rapid Entire Body Assessment), OWAS (Ovako Working Posture Analysis System), RULA (Rapid Upper limb Assessment), dan OCRA checklist. Langkah-langkah pengumpulan dan pengolahan data yakni: Dokumentasi Aktivitas Operator; Penentuan Elemen Operasi Dasar; Penilaian Domain Ergonomi; Pemberian dan Evaluasi Skor; Penilaian Akhir Ergonomi. Kemudian dilakukan analisis data dengan menganalisis keluhan muskuloskeletal pada operator produksi batik cap, postur kerja yang beresiko menyebabkan gangguan muskuloskeletal dengan pendekatan Visual Management. Analisa dilakukan terhadap sikap kerja pekerja yang salah dan rawan cidera muskuloskeletal.

\section{HASIL DAN PEMBAHASAN}

\subsection{Penentuan Stasiun Kerja dengan PLIBEL Checklist}

Terdapat 21 pertanyaan yang ditanyakan kepada operator. Kuesioner Plibel Terlampir. Kuesioner tersebut berisi pertanyaan mengenai faktor terjadinya resiko Musculoskeletal Disorder dan mengenai faktor lingkungan dan organisasi pada perusahaan. Pertanyaan faktor terjadinya resiko Musculoskeletal Disorder meliputi lima bagian tubuh yang dinilai yaitu tubuh bagian leher, bahu, dan punggung atas, tubuh bagian siku, lengan bawah dan tangan, tubuh bagian kaki, tubuh bagian lutut dan pinggul, dan tubuh bagian punggung bawah.

\subsection{Penilaian Resiko dengan Visual Management}

Pengumpulan data penelitian dilakukan dengan melakukan pengamatan secara langsung dengan melakukan perekaman video untuk merekam proses perakitan di home industry Batik Cap Putri Mulyo. Data yang telah dihimpun dijadikan input pengolahan data untuk menyelesaikan masalah. Pengolahan data dilakukan dengan menggunakan metode visual management terbagi menjadi 4 langkah, yaitu: pembagian ke dalam operasi dasar (elementary operation), penilaian ergonomi, evaluasi skor dan penilaian rekapitulasi ergonomi. Input yang diperlukan berupa sudut tubuh didapatkan dengan pengukuran sudut menggunakan SolidWorks software. Hasil dari analisis postur kerja dengan pendekatan visual management berupa keseluruhan skor ergonomi atau OES (Overall Ergonomic Scores). OES memiliki empat interval yang memberikan indikasi kekritisan postur kerja disertai dengan derajat kepentingan perbaikan sistem kerja.

\subsection{Penilaian Ergonomi}

Domain yang dipilih untuk masuk dalam penilaian ergonomi ada 9, yaitu; sudut batang tubuh membungkuk, ketinggian lengan, sudut lutut menekuk, jumlah langkah berjalan, beban yang ditangani (kilogram), sudut menekuk leher atau memutar, sudut memutar lengan bawah, posisi kaki dan sudut menekuk pergelangan tangan.

\subsection{Penilaian Rekapitulasi Ergonomi Setelah Perancangan}

Berdasarkan nilai OES yang telah dihitung sebelumnya terhadap setiap operasi dasar, maka didapatkan hasil sebagai berikut.

Tabel 4.1 Nilai OES dan Status Operasi Di Stasiun Perakitan

\begin{tabular}{|c|l|c|l|}
\hline No & Proses Pada Stasiun Pewarnaan & OES & \multicolumn{1}{|c|}{ Status Operasi } \\
\hline 1 & Mencampur bahan pewarna & 0,40 & Diterima \\
\hline 2 & Mencampur larutan waterglass & 0,40 & Diterima \\
\hline 3 & Mengambil kain hasil pengecapan & 0,43 & $\begin{array}{l}\text { Diperlukan investigasi lebih } \\
\text { lanjut, }\end{array}$ \\
\hline 4 & $\begin{array}{l}\text { Mencelupkan kain kedalam bak } \\
\text { pewarnan }\end{array}$ & 0,42 & $\begin{array}{l}\text { Diperlukan investigasi lebih } \\
\text { lanjut, }\end{array}$ \\
\hline 5 & $\begin{array}{l}\text { Menutup kain hasil pewarnaan } \\
\text { dengan plastik }\end{array}$ & 0,40 & Diterima \\
\hline
\end{tabular}

Berdasarkan penilaian postur kerja dengan metode visual management, diperoleh nilai OES dan status operasi setiap proses di stasiun perakitan seperti yang ditunjukkan pada Tabel 4.166. Terdapat 3 proses dengan nilai $\mathrm{OES} \leq 0.4$ yaitu proses mencampur bahan pewarna, mencampur larutan waterglass, menutup kain hasil pewarnaan dengan plastik dan 2 proses dengan nilai OES berada pada rentang $0.4<$ OES $\leq 0.5$ yaitu proses mengambil kain hasil pengecapan, mencelupkan kain kedalam bak pewarnan dengan status operasi menjadi 'diperlukan investigasi lebih lanjut, perubahan mungkin diperlukan' 


\section{KESIMPULAN DAN SARAN}

Kesimpulan yang dihasilkan dari penelitian ini adalah Menghasilkan suatu design rancangan alat bantu yang untuk mengurangi keluhan dan memperbaiki postur kerja saat melakukan proses pewarnaan kain batik. Rancangan alat bantu yang dihasilkan dapat mengurangi level resiko postur kerja dari awal sebelum rancangan memiliki nilai OES pada stasiun pewarnaan menunjukan bahwa hasil nilai OES menunjukan 3 proses dengan nilai OES $\leq 0.4$ dengan status operasi diterima dan 2 proses dengan nilai OES berada pada rentang $0.4<\mathrm{OES} \leq 0.5$, dengan status operasi menjadi 'diperlukan investigasi lebih lanjut, perubahan mungkin diperlukan. Rancangan alat bantu yang dihasilkan berupa bak pewarnaan dengan penambahan tempat pencampuran warna disamping yang dilengkapi dengan kran air untuk mempermudah memindahkan pewarna dan waterglass tanpa harus menuangkan secara manual, sehingga operator tidak perlu melakukan proses pemindahan pewarna dan waterglass secara berulang-ulang. Saran yang dapat diberikan terhadap penelitian lebih lanjut, yaitu penelitian selanjutnya sebaiknya perancangan bak pewarnaan dapat diwujudkan secara nyata dan diaplikasikan langsung ke perusahaan sehingga dapat mengevaluasi kekurangan hasil dari rancangan dan sebaiknya diperhatikan juga alat bantu untuk aktivitas manual material handling pada proses pengambilan kain.

\section{DAFTAR PUSTAKA}

Bridger. 1995. Introduction to Ergonomics. McGraw-Hill. Singapore

Bridger, R.S. 2003. Introduction to Ergonomics. New York: Taylor \& Francis Inc.

Grandjean, E. 1987. Ergonomics in Computerized Office. London: Taylor \& Francis.

M. Hagberg et al. WMSDs: A Reference Book for Prevention. London: Taylor \& Francis

Savino et al.2016. New easy to use postural assessment method through visual management. International Journal of Industrial Ergonomics.

Stanton, Neville A.. Hedge, Alan, .Salas, Eduardo,. Hendrick, Hal W. and Brookhuis, Karel. 2005. The Handbook of Human Factors and Ergonomics methods, CRC press. Hal.3-1.

Tarwaka. 2010. Ergonomi Industri Dasar-Dasar Pengetahuan Ergonomi dan Aplikasi di Tempat Kerja. Surakarta: Harapan Press. 